LETTERS

\section{Animal protein intake and hepatic steatosis in the elderly: authors' response}

We would like to thank Tang and Mann for their interest in our study in which we showed that animal protein intake was independently associated with higher prevalence of non-alcoholic fatty liver disease (NAFLD) in an overweight, predominantly aged Caucasian population. ${ }^{12}$

Rightfully so, the authors express their concerns regarding the generalisability of our findings towards younger patients with clinically significant non-alcoholic steatohepatitis (NASH). ${ }^{1}$ Indeed, our results only pertain to our study population, consisting of an elderly and presumably healthy population in which the vast majority will have NAFLD, not NASH. Nonetheless, we believe that aiming for a healthy lifestyle, such as adherence to a healthy diet, is key across the entire spectrum of NAFLD and is not reserved for advanced disease only. ${ }^{3}$ Also, Tang and Mann question the clinical significance of NAFLD as a liver disease at the age of 70 years, but patients with NAFLD are, in fact, twice as likely to die from cardiovascular disease than from liver disease itself. ${ }^{4}$ As cardiovascular disease is a clinically relevant disease in the elderly, we do believe that NAFLD embodies a relevant trait in our population with a mean age of 70 years.

Other remarks that are put forward in the letter were, in fact, already elaborated on in the discussion of our paper. ${ }^{12}$ Briefly, energy intake as assessed by a semiquantitative food-frequency questionnaire is not reliable because it is known to be under-reported. ${ }^{5}$ This under-reporting does generally not affect the energy-adjusted macronutrient composition of the diet. In addition, we extensively adjusted for energy intake in various ways ${ }^{6}$ to account for extraneous variation and potential measurement error. Second, we have not studied mechanistic pathways underlying our findings. We have merely discussed two already established hypotheses to explain the association between animal protein and NAFLD. Future studies are needed to explore these hypotheses in depth before conclusions can be drawn. Finally, in contrast to the impression by Tang and Mann, our main findings are not that surprising at all. Mounting evidence from other large population studies (with an average age of about 55 years) support our results on animal protein being associated with higher prevalence of NAFLD. ${ }^{78}$ Also, the presumable detrimental effect of monosaccharides and disaccharides is thought to be only true in presence of excess caloric intake or related to specific food sources such as sugar-containing beverages, for which we already corrected in our analyses. ${ }^{9}$

In conclusion, our population-based study gives insight into the correlation between macronutrients and NAFLD. However, mechanistic and (randomised) intervention studies are ultimately needed to explore causality before recommendations can be made.

Louise Johanna Maria Alferink ๑ ,

Jessica Christina Kiefte-de Jong $\circledast^{2,3}$

Sarwa Darwish Murad

'Department of Gastroenterology and Hepatology, Erasmus MC University Medical Centre, Rotterdam, The Netherlands

${ }^{2}$ Department of Epidemiology, Erasmus MC University Medical Centre, Rotterdam, The Netherlands

${ }^{3}$ Department of Public Health and Primary Care, Leiden

University Medical Centre, The Hague, The Netherlands

Correspondence to Dr Sarwa Darwish Murad, Department of Gastroenterology and Hepatology, Erasmus Medical Centre, Rotterdam, CA 3000, The Netherlands; s.darwishmurad@erasmusmc.nl

Contributors All authors have actively contributed to the intellectual content of this response. All authors have read and approved the final version of the response.

Competing interests None declared.

Patient consent Not required.

Provenance and peer review Not commissioned; internally peer reviewed.

(c) Author(s) (or their employer(s)) 2020. No commercial re-use. See rights and permissions. Published by BMJ.

Check for updates

To cite Alferink LJM, Kiefte-de Jong JC, Darwish Murad S. Gut 2020;69:189.

Received 1 November 2018

Accepted 4 November 2018

Published Online First 21 November 2018

Gut 2020;69:189. doi:10.1136/gutjnl-2018-317843

ORCID iDs

Louise Johanna Maria Alferink http://orcid.org/00000001-7342-4654

Jessica Christina Kiefte-de Jong http://orcid.org/00000002-8136-0918

\section{REFERENCES}

1 Tang GY, Mann JP. Animal protein intake and hepatic steatosis in the elderly. Gut 2019:68:2256-7.

2 Alferink LJ, Kiefte-de Jong JC, Erler NS, et al. Association of dietary macronutrient composition and non-alcoholic fatty liver disease in an ageing population: the Rotterdam Study. Gut 2019;68:1088-98.

3 Rinella ME. Nonalcoholic fatty liver disease: a systematic review. JAMA 2015;313:2263-73.

4 Friedman SL, Neuschwander-Tetri BA, Rinella M, et al. Mechanisms of NAFLD development and therapeutic strategies. Nat Med 2018;24:908-22.

5 Gemming L, Jiang Y, Swinburn B, et al. Under-reporting remains a key limitation of self-reported dietary intake: an analysis of the 2008/09 New Zealand Adult Nutrition Survey. Eur J Clin Nutr 2014;68:259-64.

6 Willet WC. Nutritional epidemiology. New York: Oxford University Press, 2012.

7 Zelber-Sagi S, Ivancovsky-Wajcman D, Fliss Isakov N, et al. High red and processed meat consumption is associated with non-alcoholic fatty liver disease and insulin resistance. J Hepatol 2018:68:1239-46.

8 Rietman A, Sluik D, Feskens EJM, et al. Associations between dietary factors and markers of NAFLD in a general Dutch adult population. Eur J Clin Nutr 2018;72:117-23.

9 Chiu S, Sievenpiper JL, de Souza RJ, et al. Effect of fructose on markers of non-alcoholic fatty liver disease (NAFLD): a systematic review and metaanalysis of controlled feeding trials. Eur J Clin Nutr 2014:68:416-23. 